\title{
Effect of presence and semiochemicals of conspecific stages on oviposition by ladybirds (Coleoptera: Coccinellidae)
}

\author{
Geetanjali MiSHRA, Neha SINGH, Mohd. SHAHID and OMKAR* \\ Ladybird Research Laboratory, Department of Zoology, University of Lucknow, Lucknow-226007, India
}

Key words. Oviposition deterring pheromone, interference, Coleoptera, conspecific, Coccinellidae

\begin{abstract}
Reduced oviposition by ladybirds in the presence of tracks of fourth instar larvae owing to the presence of oviposition deterring pheromones is well established across many genera. However, deterrence, if any, by other life stages has not been well investigated, in particular the effect of conspecific presence. The present study investigates the effects of conspecific presence and semiochemicals of conspecific life stages (eggs, fourth instar larvae, pupae, adult males and females) on oviposition by five ladybird (Coleoptera: Coccinellidae) species, viz. Coccinella septempunctata, Coccinella transversalis, Cheilomenes sexmaculata, Propylea dissecta and Anegleis cardoni. Results reveal that the presence of life stages inhibits oviposition and the inhibition is densitydependent, although the degree of inhibition is species-specific. Surface semiochemicals of eggs and larval and adult tracks also show density-dependent inhibitory effects. Moreover, the semiochemicals in tracks (oviposition deterring pheromones) and egg surface semiochemicals are not similar, indicating semiochemical parsimony. Of all species tested, C. transversalis and C. septempunctata were the most and the least responsive to both conspecific presence and semiochemicals, respectively.
\end{abstract}

\section{INTRODUCTION}

Oviposition site selection is a critical determinant of female fitness. A suitable oviposition site is postulated to have: (a) an optimum microclimate for embryonic development, (b) availability of food in proximity for offspring, and (c) low probability of parasitism, predation or pathogenic infection (Pasteels et al., 1986; Dixon, 2000; Seagraves, 2009). During the selection of suitable oviposition sites, coccinellid females may evaluate: (a) patch quality and quantity of food (Hemptinne et al., 2000a; Fréchette et al., 2006; Oliver et al., 2006), (b) the cost of inter-patch movement (in energy and time), and (c) mortality risks (Hilker \& Meiners, 2002; Seagraves, 2009).

The process of oviposition site selection and its consequences have led to the application of optimal foraging theory to aphidophagous ladybirds (Kindlmann \& Dixon, 1993; Dixon, 1997), and the postulation of an "oviposition window" in the exponential growth phase of the aphid population. Oviposition in this window is hypothesized to optimize offspring development and survival and thus female fitness (Dixon, 2000). The opening of this window is determined by the minimum density of aphids required for complete development of larvae (Dixon, 1959; Evans \& Dixon, 1986). Honeydew (Wiedemann et al., 2004; Kazana et al., 2007), aphid alarm pheromones (Pettersson et al., 1995, 2008; Quiroz et al., 1997), plant volatiles released in response to infestations ( $\mathrm{Zhu}$ et al., 1999; Birkett et al., 2000; Zhu \& Park, 2005; Alhmedi et al., 2010) and species-specific plant substances (Schaller \& Nentwig, 2000; Pettersson et al., 2005) may all serve to orient ladybirds towards aphid patches (Hatano et al., 2008; Petterson et al., 2008).

The closing of the window is determined by the maturation of aphid colony (Kan, 1988a, b), as indicated by the presence of alate aphids (Kan \& Sasakawa, 1986) and larval tracks (Růžička, 2001a, 2003; Magro et al., 2007, 2010). The inhibitory effect of the presence of conspecific larvae on oviposition was first reported in Adalia bipunctata (Linnaeus) (Hemptinne \& Dixon, 1991). Thereafter, the oviposition deterring effects of larval tracks have been identified in a number of ladybirds (Růžička, 1997, 2001a, b, 2002, 2003, 2006; Yasuda et al., 2000) and that of adult tracks in Propylea dissecta (Mulsant) (Mishra \& Omkar, 2006). The effect of oviposition deterring pheromone (ODP) has been most intensively studied in coccinellids but in such arenas that allowed contact with conspecific females, a situation that has been shown to affect oviposition behavior in aphid parasitoids (Michaud \& Mackauer, 1995) and coccinellids (Hemptinne et al., 1993; Mishra \& Omkar, 2006), with an increased incident of superparasitism being observed in the former. To account for the possibly important influences of prey, host plant and conspecific interference, Yasuda et al. (2000) and Michaud \& Jyoti (2007) studied oviposition responses by solitary females to larval tracks in Harmonia axyridis (Pallas) and Coccinella septempunctata Linnaeus, and Hippodamia convergens Guerin respectively, in the presence of host plants and aphids. It is also now known that the secretion of ODP takes place from the anal disk on the $10^{\text {th }}$ abdominal segment of larvae (Laubertie et al., 2006). Hemptinne et al. (2001) attributed ODP effect to a mixture of discovered alkanes

\footnotetext{
* Corresponding author; e-mail: omkaar55@hotmail.com
} 
TABLE 1. Two way ANOVA showing the effects of egg density, clustering pattern and their interactions on oviposition.

\begin{tabular}{ccccc}
\hline Ladybird species & Factors & F-value & P-value & DF \\
\hline & Egg density & 12.09 & 0.001 & 4,99 \\
C. septempunctata & Clustering pattern & 402.88 & 0.001 & 1,99 \\
& Egg density $\times$ Clustering pattern & 0.53 & 0.312 & 4,99 \\
\hline & Egg density & 15.72 & 0.001 & 4,99 \\
C. transversalis & Clustering pattern & 0.83 & 0.365 & 1,99 \\
& Egg density $\times$ Clustering pattern & 0.14 & 0.968 & 4,99 \\
\hline & Egg density & 12.02 & 0.001 & 4,99 \\
C. sexmaculata & Clustering pattern & 0.98 & 0.325 & 1,99 \\
& Egg density $\times$ Clustering pattern & 0.38 & 0.822 & 4,99 \\
\hline P. dissecta & Egg density & 5.46 & 0.001 & 4,99 \\
& Clustering pattern & 15.72 & 0.001 & 1,99 \\
A. cardoni & Egg density $\times$ Clustering pattern & 1.12 & 0.354 & 4,99 \\
\hline & Egg density & 12.02 & 0.001 & 4,99 \\
\hline
\end{tabular}

with the major component n-pentacosane. In a recent study, (z)-Pentacos-12-ene, was found to be solely an ODP of Cheilomenes sexmaculata (Fabricius) (Klewer et al., 2007). The predominantly alkane constituents of ODP have been attributed as the reason for the long lasting signal (Hemptinne et al., 2001). Studies on A. bipunctata (Doumbia et al., 1998) and P. dissecta (Mishra \& Omkar, 2006), indicate the effects of ODP to be densitydependent and not age or sex-specific. Further, the response of $A$. bipunctata to ODP has been found to be modified by age and experience of the ovipositing female (Fréchette et al., 2004).

The oviposition deterrence of larval tracks also extends to heterospecifics (Rủžička, 2001a; 2003; Magro et al., 2007, 2010). The ODP primarily signals the presence and density of larvae in a patch, thereby allowing assessment of predation and cannibalism risk to eggs that may be laid (Martini et al., 2009; Moser et al., 2010; Meisner et al., 2011). Studies indicate that the deterrence induced by ODP is more prominent amongst conspecifics than heterospecifics owing to qualitative similarity; the closer the phylogenetic relations, the more the deterrence (Michaud \& Jyoti 2007; Magro et al., 2007, 2010).

Most of the studies on oviposition deterrence in ladybirds have concentrated on larval presence (primarily semiochemical presence, but a few with actual presence) and have ignored the possible role of other life stages in the process. Only a few studies discuss the role of egg (Hemptinne \& Dixon, 1991; Hemptinne et al., 1993), pupal (Hemptinne \& Dixon, 1991) or adult presence (Hemptinne et al., 1992, 1993; Mishra \& Omkar, 2006) and/or their semiochemicals in influencing oviposition (Doumbia et al., 1998; Mishra \& Omkar, 2006). Previous studies have found no influence of egg and pupal presence on oviposition (Hemptinne \& Dixon, 1991; Hemptinne et al., 1993). Adult ladybirds known to leave tracks include Epilachna vigintioctomaculata, Epilachna vigintioctopunctata (Fabricius) and C. septempunctata (Kosaki \& Yamaoka, 1996; Nakashima et al., 2004).
These were found to cause no oviposition deterrence in $A$. bipunctata (Doumbia et al., 1998), whereas the opposite was observed in P. dissecta (Mishra \& Omkar, 2006).

In view of the ambiguity on oviposition deterrence by the presence of adults or their semiochemical residues, and the lack of information on deterrence by most life stages in five locally abundant ladybird species, viz. Anegleis cardoni (Weise) (Ac), C. sexmaculata (Cs), C. septempunctata (C7), Coccinella transversalis Fabricius $(\mathrm{Ct})$ and $P$. dissecta $(\mathrm{Pd})$, the present study was undertaken. We studied here the role of varying densities of actual and semiochemical presence of conspecific life stages (egg, fourth instar larvae, pupae, adult males and females) on oviposition deterrence. We hypothesized that the presence and/or semiochemicals of motile stages (i.e., larvae and adults) will deter oviposition, whereas that of the eggs and pupae would not, as they do not pose any danger of cannibalism to eggs.

\section{MATERIAL AND METHODS}

\section{Stock maintenance}

Approximate 50 adults each of Ac, Cs, C7, Ct and Pd were collected from agricultural fields surrounding Lucknow, India $\left(26^{\circ} 50^{\prime} \mathrm{N}, 80^{\circ} 54^{\prime} \mathrm{E}\right)$. They were paired for mating in transparent plastic Petri dishes $(9.0 \times 2.0 \mathrm{~cm})$ containing pea aphid, Acyrthosiphon pisum (Harris) (on the host plant Vigna unguiculata taken from glasshouse cultures $21 \pm 1{ }^{\circ} \mathrm{C} ; 65 \pm 5 \%$ R.H.) under laboratory conditions $\left(27 \pm 1{ }^{\circ} \mathrm{C} ; 65 \pm 5 \%\right.$ R.H.; $14 \mathrm{~L}$ : 10D). Males were removed after mating. Food was replaced and the eggs laid were collected every $24 \mathrm{~h}$ and incubated under the above abiotic conditions until hatching. The larvae were reared until adult emergence in plastic beakers $(14.5 \times 10.5 \mathrm{~cm} ; 5$ larvae per beaker). The requisite stages were taken from the stock culture for experiments.

\section{Experimental design}

\section{Presence of conspecific eggs}

A single 10-day-old conspecific once-mated female (referred to hereafter as focal female) was weighed (Sartorius CP225-D; $0.01 \mathrm{mg}$ precision) and placed in a Petri dish $(14.5 \times 1.5 \mathrm{~cm})$ containing 5 freshly laid conspecific eggs $(<12 \mathrm{~h}$ old $)$ in cluster 

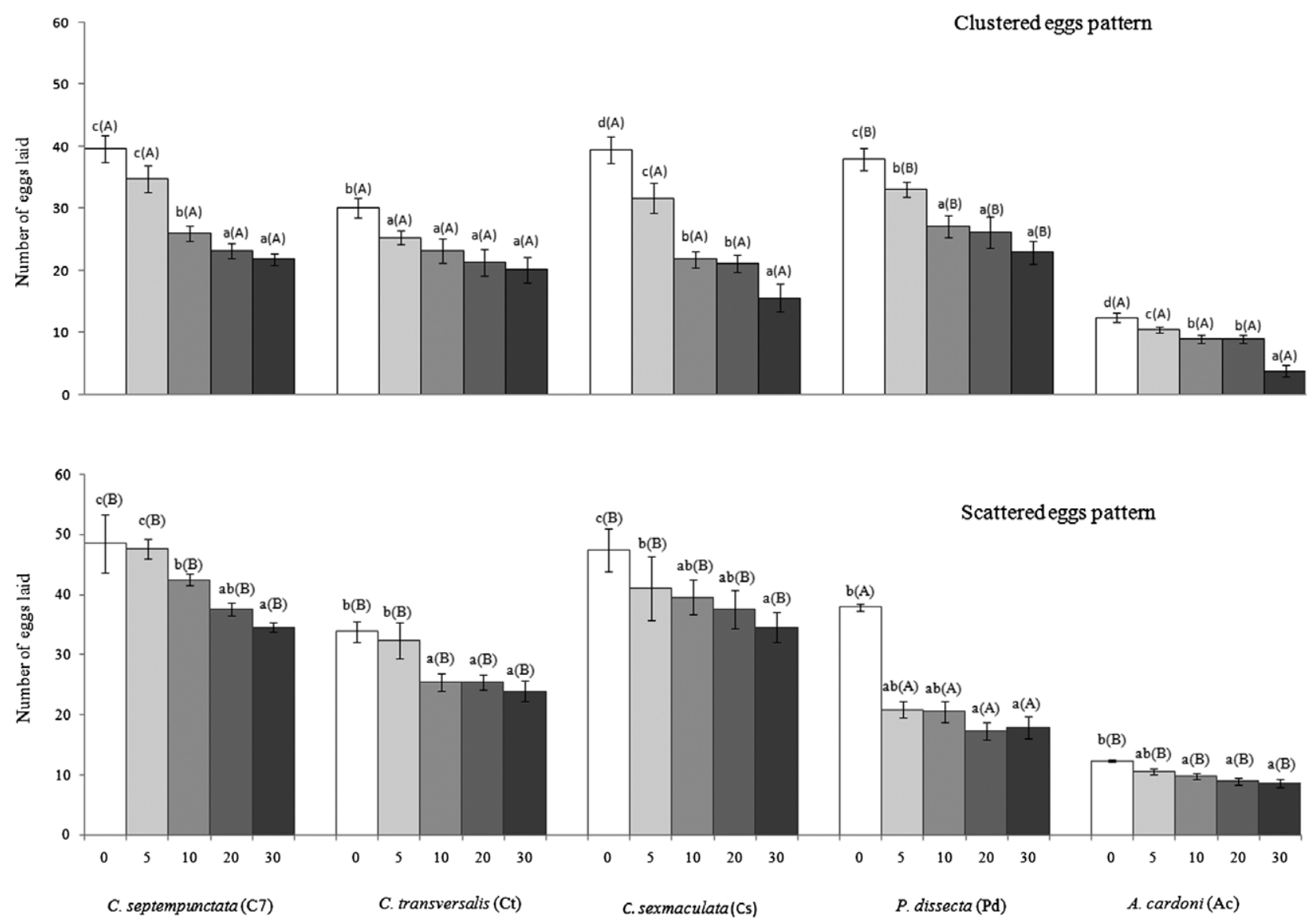

Number of conspecific eggs

Fig. 1. Mean $( \pm$ SE) numbers of eggs laid in $24 \mathrm{~h}$ by $10 \mathrm{~d}$-old female coccinellids $(\mathrm{n}=10)$ of five species in $14.5 \times 1.5 \mathrm{~cm}$ Petri dishes in the presence of aphids and different numbers of conspecific eggs arranged in clustered and scattered pattern. Values are Mean \pm SE. For each ladybird species, small and large alphabets (placed in parentheses) represent comparison of means between different egg density levels within and between egg patterns, respectively. Similar alphabets indicate lack of significant differences amongst means of a species.

in the centre of the dish. Eggs were removed and placed with the help of wet fine camel hair brush. Aphids $(50 \mathrm{mg}$ freshly weighted, without plant material) were provided along with the eggs. After $24 \mathrm{~h}$ the number of eggs laid, amount of aphids consumed, and weight of the females were recorded. The same treatment was repeated with an equal number of eggs dispersed (scattered) in the Petri dish, to assess the effects of clustering pattern on oviposition, if any. The placement of eggs was recorded with a marker pen.

The above treatments were repeated with 10,20 and 30 eggs in all five ladybird species $(\mathrm{n}=10$ per treatment). For the control, females were placed in Petri dishes containing equal amount of aphids but no eggs and the same observations were recorded.

Presence of conspecific larvae, pupae, adult males and females

A single 10-day-old focal female was weighed and placed in a Petri dish $(14.5 \times 1.5 \mathrm{~cm})$ containing 2 conspecific well fed fourth instar larvae along with $50 \mathrm{mg}$ of aphids per insect. After $24 \mathrm{~h}$, number of eggs laid, amount of aphids consumed and body weight of females were recorded. The treatment was repeated with 4 and 6 fourth instar larvae in each of the five ladybird species (food@50 mg of aphids per insect). For the control, female was placed in the Petri dish with no fourth instar larvae but with an equal amount of aphids. Voracity of focal female was taken as an average of total aphid consumption within $24 \mathrm{~h}$. All treatments were repeated 10 times.

The influence of presence of varying densities of conspecific pupae, adult males and females were assessed, following the above mentioned protocol, replacing larvae with the requisite stages. Pupae employed in the experiment were used within 12 $\mathrm{h}$ of their formation. Conspecific pupae were removed from their formation site with the help of fine mounted needle and brush prior to their shifting to experimental arena. Care was taken not to damage them and they were reattached with the help of odourless diluted glue. Adult males and females used as interfering individuals in the experiment were 10-day-old virgins. Interfering conspecific females did not lay eggs as they were not mated.

\section{Hexane extract of conspecific eggs}

To obtain semiochemicals from the surface of eggs, the requisite numbers (viz. 5, 10, 20 and 30) used in experiment (A) were transferred to a corked tube containing $2 \mathrm{ml}$ of n-hexane $95 \%$ LR (Company-SDFCL, Product and Pack code 38487 L25) for 2 min (Chan, 1995), with the help of a fine wet camel hair brush. Only undamaged eggs were used for the experiment. Thereafter, the entire $2 \mathrm{ml}$ of hexane extract of eggs was painted at the centre of Petri dishes $(14.5 \times 1.5 \mathrm{~cm}) .50 \mathrm{mg}$ aphids were introduced along with a weighed 10-day-old conspecific oncemated female. After $24 \mathrm{~h}$, number of eggs laid, amount of 
TABle 2. Oviposition by ladybird females in presence of varying densities of different life stages. Two way ANOVA showing the effects of stage (larvae, pupae, adult males and females), density and their interactions on oviposition.

\begin{tabular}{|c|c|c|c|c|c|c|}
\hline $\begin{array}{l}\text { Interfering } \\
\text { stage }\end{array}$ & Density & $\begin{array}{l}\text { C. septempunctata } \\
\text { (C7) }\end{array}$ & $\begin{array}{l}\text { C. transversalis } \\
(\mathrm{Ct})\end{array}$ & $\begin{array}{l}\text { C. sexmaculata } \\
\text { (Cs) }\end{array}$ & $\begin{array}{l}\text { P. dissecta } \\
(\mathrm{Pd})\end{array}$ & $\begin{array}{l}\text { A. cardoni } \\
\text { (Ac) }\end{array}$ \\
\hline \multirow{4}{*}{$4^{\text {th }}$ instar } & 0 & $46.80 \pm 1.99^{\mathrm{a}(\mathrm{A})}$ & $32.00 \pm 1.43^{\mathrm{b}(\mathrm{D})}$ & $43.00 \pm 2.35^{\mathrm{a}(\mathrm{C})}$ & $38.00 \pm 1.88^{\mathrm{a}(\mathrm{C})}$ & $11.20 \pm 0.71^{\mathrm{a}(\mathrm{C})}$ \\
\hline & 2 & $44.90 \pm 2.50^{\mathrm{a}(\mathrm{A})}$ & $24.70 \pm 3.04^{\mathrm{b}(\mathrm{C})}$ & $35.90 \pm 1.87^{\mathrm{a}(\mathrm{B})}$ & $33.10 \pm 3.69^{\mathrm{a}(\mathrm{B})}$ & $7.60 \pm 1.29^{\mathrm{a}(\mathrm{B})}$ \\
\hline & 4 & $36.70 \pm 2.80^{\mathrm{a}(\mathrm{A})}$ & $15.30 \pm 2.74^{\mathrm{b}(\mathrm{B})}$ & $34.40 \pm 3.03^{\mathrm{a}(\mathrm{AB})}$ & $30.10 \pm 2.67^{\mathrm{a}(\mathrm{B})}$ & $4.30 \pm 1.04^{\mathrm{a}(\mathrm{AB})}$ \\
\hline & 6 & $39.50 \pm 3.65^{\mathrm{a}(\mathrm{A})}$ & $9.20 \pm 1.89^{\mathrm{a}(\mathrm{A})}$ & $32.70 \pm 2.48^{\mathrm{ab}(\mathrm{A})}$ & $22.60 \pm 2.22^{\mathrm{a}(\mathrm{A})}$ & $3.70 \pm 0.96^{\mathrm{a}(\mathrm{A})}$ \\
\hline \multirow{4}{*}{ Pupa } & 0 & $47.20 \pm 3.45^{\mathrm{b}(\mathrm{A})}$ & $31.00 \pm 1.59^{\mathrm{b}(\mathrm{A})}$ & $44.30 \pm 1.22^{\mathrm{b}(\mathrm{A})}$ & $35.40 \pm 1.78^{\mathrm{a}(\mathrm{C})}$ & $10.10 \pm 0.84^{\mathrm{a}(\mathrm{A})}$ \\
\hline & 2 & $44.20 \pm 3.21^{\mathrm{a}(\mathrm{A})}$ & $29.10 \pm 1.94^{\mathrm{c}(\mathrm{A})}$ & $43.60 \pm 3.16^{\mathrm{b}(\mathrm{A})}$ & $34.00 \pm 2.24^{\mathrm{a}(\mathrm{B})}$ & $9.70 \pm 0.84^{\mathrm{b}(\mathrm{A})}$ \\
\hline & 4 & $45.30 \pm 1.62^{\mathrm{b}(\mathrm{A})}$ & $28.40 \pm 1.84^{\mathrm{d}(\mathrm{A})}$ & $43.60 \pm 1.64^{\mathrm{b}(\mathrm{A})}$ & $31.00 \pm 3.08^{\mathrm{a}(\mathrm{AB})}$ & $8.90 \pm 0.91^{\mathrm{b}(\mathrm{A})}$ \\
\hline & 6 & $47.00 \pm 2.48^{\mathrm{b}(\mathrm{A})}$ & $27.90 \pm 1.70^{\mathrm{c}(\mathrm{A})}$ & $42.10 \pm 3.39^{\mathrm{b}(\mathrm{A})}$ & $26.10 \pm 2.28^{\mathrm{a}(\mathrm{A})}$ & $8.10 \pm 0.87^{\mathrm{b}(\mathrm{A})}$ \\
\hline \multirow{4}{*}{ Adult male } & 0 & $48.30 \pm 3.75^{\mathrm{b}(\mathrm{A})}$ & $28.00 \pm 1.59^{\mathrm{a}(\mathrm{C})}$ & $47.20 \pm 2.65^{\mathrm{b}(\mathrm{C})}$ & $37.25 \pm 1.65^{\mathrm{a}(\mathrm{C})}$ & $10.50 \pm 0.89^{\mathrm{a}(\mathrm{C})}$ \\
\hline & 2 & $47.60 \pm 2.20^{\mathrm{a}(\mathrm{A})}$ & $17.10 \pm 2.83^{\mathrm{a}(\mathrm{B})}$ & $45.50 \pm 2.24^{\mathrm{b}(\mathrm{C})}$ & $33.00 \pm 3.92^{\mathrm{a}(\mathrm{B})}$ & $7.00 \pm 0.47^{\mathrm{a}(\mathrm{B})}$ \\
\hline & 4 & $43.50 \pm 3.33^{\mathrm{b}(\mathrm{A})}$ & $9.00 \pm 2.72^{\mathrm{a}(\mathrm{A})}$ & $41.60 \pm 3.16^{\mathrm{b}(\mathrm{B})}$ & $29.70 \pm 2.51^{\mathrm{a}(\mathrm{B})}$ & $3.50 \pm 0.87^{\mathrm{a}(\mathrm{A})}$ \\
\hline & 6 & $42.90 \pm 3.68^{\mathrm{a}(\mathrm{A})}$ & $8.70 \pm 2.41^{\mathrm{a}(\mathrm{A})}$ & $26.80 \pm 2.44^{\mathrm{a}(\mathrm{A})}$ & $17.90 \pm 1.96^{\mathrm{a}(\mathrm{A})}$ & $2.70 \pm 0.86^{\mathrm{a}(\mathrm{A})}$ \\
\hline \multirow{4}{*}{ Adult female } & 0 & $48.40 \pm 3.81^{\mathrm{b}(\mathrm{A})}$ & $30.00 \pm 1.59^{\mathrm{b}(\mathrm{C})}$ & $46.50 \pm 2.82^{\mathrm{b}(\mathrm{B})}$ & $36.37 \pm 1.29^{\mathrm{a}(\mathrm{B})}$ & $10.90 \pm 0.99^{\mathrm{a}(\mathrm{C})}$ \\
\hline & 2 & $49.80 \pm 3.83^{\mathrm{a}(\mathrm{A})}$ & $26.80 \pm 3.15^{\mathrm{c}(\mathrm{B})}$ & $46.10 \pm 3.65^{\mathrm{b}(\mathrm{B})}$ & $32.80 \pm 5.65^{\mathrm{a}(\mathrm{A})}$ & $7.90 \pm 1.07^{\mathrm{a}(\mathrm{BC})}$ \\
\hline & 4 & $44.20 \pm 2.84^{\mathrm{b}(\mathrm{A})}$ & $18.10 \pm 3.04^{\mathrm{c}(\mathrm{A})}$ & $42.30 \pm 2.80^{\mathrm{b}(\mathrm{A})}$ & $30.10 \pm 2.34^{\mathrm{a}(\mathrm{A})}$ & $6.20 \pm 0.96^{\mathrm{a}(\mathrm{B})}$ \\
\hline & 6 & $43.90 \pm 3.51^{\mathrm{a}(\mathrm{A})}$ & $16.80 \pm 3.50^{\mathrm{b}(\mathrm{A})}$ & $41.90 \pm 3.51^{\mathrm{b}(\mathrm{A})}$ & $29.10 \pm 2.56^{\mathrm{a}(\mathrm{A})}$ & $4.40 \pm 0.83^{\mathrm{a}(\mathrm{A})}$ \\
\hline \multicolumn{2}{|c|}{$\begin{array}{l}\mathrm{F}_{\text {Stage }}(\mathrm{P}-\mathrm{v} \text { alue }) ; \\
\mathrm{df}\end{array}$} & $\begin{array}{c}3.00(<0.0001) \\
3,159\end{array}$ & $\begin{array}{c}5.53(<0.0001) \\
3,159 \\
\end{array}$ & $\begin{array}{c}6.47(<0.0001) \\
3,159 \\
\end{array}$ & $\begin{array}{c}2.49(0.063) \\
3,159 \\
\end{array}$ & $\begin{array}{c}2.07 \text { (0.107); } \\
3,159 \\
\end{array}$ \\
\hline \multicolumn{2}{|c|}{$\begin{array}{l}\mathrm{F}_{\text {Density }}(\mathrm{P} \text {-value }) \\
\mathrm{df}\end{array}$} & $\begin{array}{c}2.38(0.073) \\
3,159 \\
\end{array}$ & $\begin{array}{c}28.84(<0.0001) \\
3,159\end{array}$ & $\begin{array}{c}5.15(0.002) \\
3,159\end{array}$ & $\begin{array}{c}16.67(<0.0001) ; \\
3,159\end{array}$ & $\begin{array}{c}14.67(<0.0001) ; \\
3,159\end{array}$ \\
\hline \multicolumn{2}{|c|}{$\begin{array}{l}F_{\text {Stage } \times \text { Density }}(P \text {-value }) \\
\text { df }\end{array}$} & $\begin{array}{c}1.08(0.384) \\
9,159\end{array}$ & $\begin{array}{c}1.64(0.109) \\
9,159 \\
\end{array}$ & $\begin{array}{c}1.78(0.076) \\
9,159\end{array}$ & $\begin{array}{c}1.18(0.313) \\
9,159\end{array}$ & $\begin{array}{c}0.83(0.588) \\
9,159\end{array}$ \\
\hline
\end{tabular}

Values are Mean \pm SE.

For each ladybird species, small alphabets represent comparison of means between interfering stages within each density level, and large alphabets in parentheses represent comparison of means between different density levels within each interfering stage.

Similar alphabets indicate lack of significant differences amongst means of a species at $\mathrm{P}<0.05$.

aphids consumed, and weight of the females were recorded. For the control treatment, females $(n=10$ per treatment) were placed in Petri dishes containing no hexane egg extract but equal amount of aphids and the above mentioned observations were recorded.

Tracks of conspecific larvae, adult males and females

Varying densities (2, 4 and 6) of 12-h starved fourth instar larvae were placed in Petri dishes for a period of $2 \mathrm{~h}$ to form tracks. Thereafter they were removed and a pre-weighed 10day-old conspecific once-mated female was placed in the Petri dish containing these tracks along with $50 \mathrm{mg}$ aphids. After $24 \mathrm{~h}$ the number of eggs laid, amount of aphids consumed, and weight of the female were recorded. For control, a female was placed in a Petri dish with no tracks but an equal amount of aphids. All treatments were repeated 10 times. The same protocol was followed for adult males and females.

\section{Statistical analysis}

Data obtained in experiments A (Presence of eggs and their distribution patterns) was subjected to two way ANOVA with density $(5,10,20,30)$ and clustering pattern (clustered and scattered) as independent factors and oviposition as dependent factor followed by Tukey's post hoc comparison of means. To assess the effects of presence interference (Experiment B) on oviposition (dependent factor), two way ANOVA was conducted for each ladybird species with stage (larvae, pupae, adult female, adult male) and density $(0,2,4,6)$ as independent factors followed by Tukey's post hoc comparison of means.
For semiochemical interference, data obtained from Experiment $\mathrm{C}$ was subjected to one way ANOVA with varying densities of egg surface semiochemicals as independent factor and oviposition as dependent factor. Data from Experiment D (semiochemical presence of life stages) was subjected to two way ANOVA with stage (larvae, adult female, adult male) and density $(0,2,4,6)$ as independent factors and oviposition as dependent factor for each ladybird species followed by Tukey's post hoc comparison of means. All statistical analyses were performed using MINITAB 16.0.

\section{RESULTS}

\section{Presence of conspecific eggs}

Results obtained from two way ANOVA revealed that oviposition by focal females of all the species $(\mathrm{C} 7, \mathrm{Ct}, \mathrm{Cs}$, $\mathrm{Pd}$ and $\mathrm{Ac}$ ) varied significantly with the density of conspecific eggs. Egg clustering had a significant oviposition deterrent effect in all except $\mathrm{Ct}$ and Cs. The interactions between egg density and clustering pattern were insignificant in all five ladybirds (Table 1).

Clustered eggs inhibited oviposition by focal females of all ladybird species except Pd more than scattered eggs. Increasing the densitiy of conspecific eggs (in both distribution patterns) increased the inhibitory effect on oviposition in focal females of all species (Fig. 1), with maximum oviposition being observed in the absence of conspecific eggs. The threshold egg density for maximum 


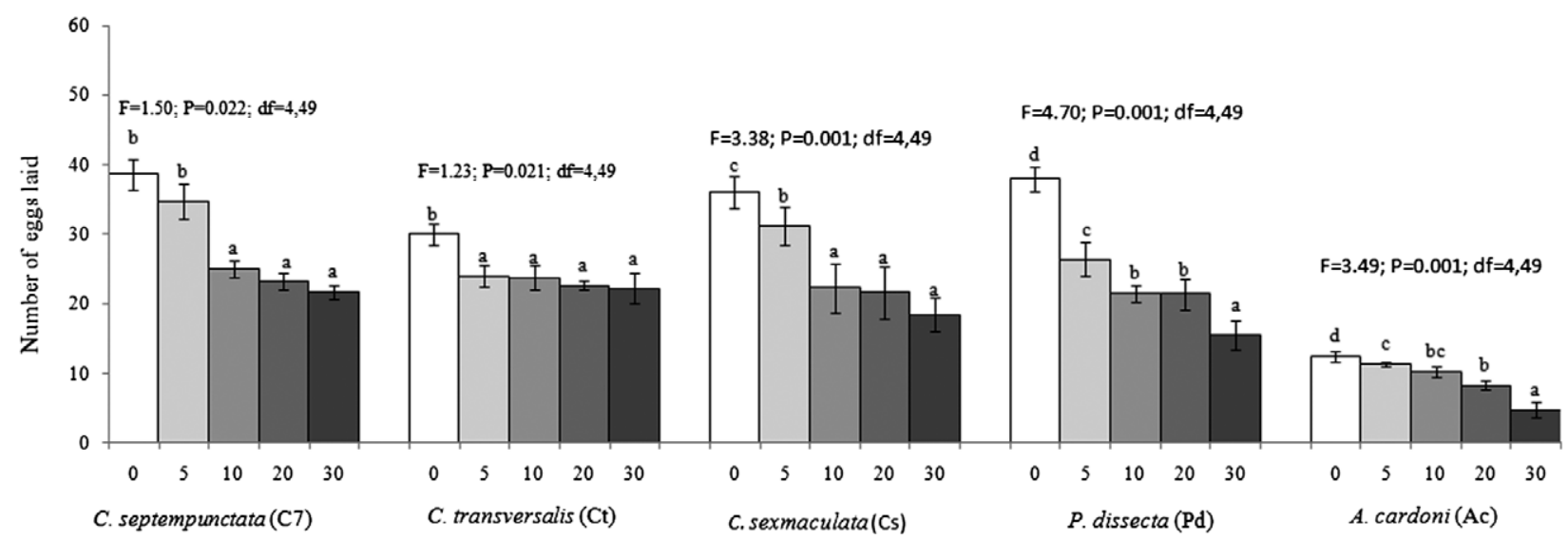

Number of conspecific eggs (Hexane extract)

Fig. 2. Mean ( \pm SE) numbers of eggs laid in $24 \mathrm{~h}$ by $10 \mathrm{~d}$-old female coccinellids $(\mathrm{n}=10)$ of five species in $14.5 \times 1.5 \mathrm{~cm}$ Petri dishes in the presence of aphids and hexane extracts of varying numbers of conspecific eggs. Values are Mean \pm SE. For each ladybird species, small alphabets represent comparison of means between different egg density levels. Similar alphabets indicate lack of significant differences amongst means of a species.

oviposition inhibition, however, varied from species to species.

\section{Presence of conspecific larvae, pupae, adult males and females}

Two way ANOVA revealed that interfering stage had significant influence on oviposition by $\mathrm{C} 7, \mathrm{Ct}$, Cs females but not on Pd and Ac. Density of stages significantly influenced oviposition by focal females in all ladybirds except C7. Interactions between stages and densities were not significant in any of the five ladybirds (Table 2).

Focal females of $\mathrm{Ct}, \mathrm{Cs}$, Pd and Ac showed reduced oviposition in the presence of increasing densities of fourth instars, adult males and females. However, increasing densities of pupal stage were deterrent only to Pd. Further, the deterrence of focal females was lowest in the presence of pupa compared to other life stages in all species tested (Table 2).

TABLE 3. Oviposition by ladybirds in the presence of varying densities of semiochemicals of different life stages. Two way ANOVA showing the effect of density of tracks, track forming stages and their interaction on oviposition.

\begin{tabular}{|c|c|c|c|c|c|c|}
\hline $\begin{array}{l}\text { Interfering } \\
\text { stage }\end{array}$ & Density & $\begin{array}{l}\text { C. septempunctata } \\
\text { (Cs) }\end{array}$ & $\begin{array}{l}\text { C. transversalis } \\
\text { (Ct) }\end{array}$ & $\begin{array}{l}\text { C. sexmaculata } \\
\text { (Cs) }\end{array}$ & $\begin{array}{l}\text { P. dissecta } \\
(\mathrm{Pd})\end{array}$ & $\begin{array}{l}\text { A. cardoni } \\
\text { (Ac) }\end{array}$ \\
\hline \multirow{4}{*}{$4^{\text {th }}$ instar } & 0 & $40.00 \pm 1.84^{\mathrm{b}(\mathrm{A})}$ & $29.70 \pm 2.51^{\mathrm{b}(\mathrm{B})}$ & $38.20 \pm 1.98^{\mathrm{b}(\mathrm{A})}$ & $34.70 \pm 1.59^{\mathrm{a}(\mathrm{C})}$ & $11.20 \pm 0.71^{\mathrm{a}(\mathrm{C})}$ \\
\hline & 2 & $37.30 \pm 3.36^{\mathrm{a}(\mathrm{A})}$ & $20.90 \pm 1.39^{\mathrm{a}(\mathrm{A})}$ & $35.30 \pm 3.36^{\mathrm{a}(\mathrm{A})}$ & $28.40 \pm 1.61^{\mathrm{a}(\mathrm{C})}$ & $10.10 \pm 1.06^{\mathrm{a}(\mathrm{C})}$ \\
\hline & 4 & $30.10 \pm 3.10^{\mathrm{a}(\mathrm{A})}$ & $20.60 \pm 1.77^{\mathrm{b}(\mathrm{A})}$ & $28.10 \pm 3.10^{\mathrm{a}(\mathrm{A})}$ & $26.20 \pm 1.91^{\mathrm{a}(\mathrm{B})}$ & $9.80 \pm 0.41^{\mathrm{c}(\mathrm{B})}$ \\
\hline & 6 & $31.80 \pm 3.49^{\mathrm{a}(\mathrm{A})}$ & $20.50 \pm 1.88^{\mathrm{a}(\mathrm{A})}$ & $28.80 \pm 3.89^{\mathrm{a}(\mathrm{A})}$ & $24.80 \pm 0.89^{\mathrm{a}(\mathrm{A})}$ & $8.10 \pm 0.60^{\mathrm{a}(\mathrm{A})}$ \\
\hline \multirow{4}{*}{ Adult male } & 0 & $35.50 \pm 4.30^{\mathrm{a}(\mathrm{A})}$ & $29.70 \pm 2.51^{\mathrm{b}(\mathrm{B})}$ & $39.80 \pm 1.89^{\mathrm{b}(\mathrm{A})}$ & $38.00 \pm 1.59^{\mathrm{b}(\mathrm{C})}$ & $11.20 \pm 0.71^{\mathrm{a}(\mathrm{B})}$ \\
\hline & 2 & $36.70 \pm 3.13^{\mathrm{a}(\mathrm{A})}$ & $28.60 \pm 3.47^{\mathrm{c}(\mathrm{B})}$ & $38.20 \pm 1.98^{\mathrm{b}(\mathrm{A})}$ & $28.00 \pm 1.69^{\mathrm{a}(\mathrm{B})}$ & $11.00 \pm 0.42^{\mathrm{a}(\mathrm{B})}$ \\
\hline & 4 & $35.20 \pm 3.88^{\mathrm{b}(\mathrm{A})}$ & $23.60 \pm 1.53^{\mathrm{c}(\mathrm{A})}$ & $35.80 \pm 3.16^{\mathrm{b}(\mathrm{A})}$ & $25.40 \pm 1.35^{\mathrm{a}(\mathrm{A})}$ & $8.90 \pm 0.56^{\mathrm{a}(\mathrm{A})}$ \\
\hline & 6 & $35.50 \pm 4.30^{\mathrm{b}(\mathrm{A})}$ & $21.40 \pm 1.70^{\mathrm{a}(\mathrm{A})}$ & $33.20 \pm 3.88^{\mathrm{b}(\mathrm{A})}$ & $24.50 \pm 1.90^{\mathrm{a}(\mathrm{A})}$ & $8.60 \pm 0.89^{\mathrm{a}(\mathrm{A})}$ \\
\hline \multirow{4}{*}{ Adult female } & 0 & $40.80 \pm 1.89^{\mathrm{b}(\mathrm{A})}$ & $25.70 \pm 1.70^{\mathrm{a}(\mathrm{C})}$ & $35.50 \pm 4.30^{\mathrm{a}(\mathrm{A})}$ & $35.00 \pm 1.55^{\mathrm{a}(\mathrm{C})}$ & $10.00 \pm 2.68^{\mathrm{a}(\mathrm{BC})}$ \\
\hline & 2 & $40.20 \pm 1.98^{\mathrm{b}(\mathrm{A})}$ & $24.00 \pm 1.63^{\mathrm{b}(\mathrm{C})}$ & $35.80 \pm 3.16^{\mathrm{a}(\mathrm{A})}$ & $31.60 \pm 1.54^{\mathrm{b}(\mathrm{B})}$ & $10.40 \pm 0.45^{\mathrm{a}(\mathrm{C})}$ \\
\hline & 4 & $38.00 \pm 3.17^{\mathrm{c}(\mathrm{A})}$ & $17.70 \pm 1.80^{\mathrm{a}(\mathrm{A})}$ & $33.20 \pm 3.88^{\mathrm{b}(\mathrm{A})}$ & $26.50 \pm 1.91^{\mathrm{a}(\mathrm{A})}$ & $9.40 \pm 0.40^{\mathrm{b}(\mathrm{B})}$ \\
\hline & 6 & $35.20 \pm 3.88^{\mathrm{b}(\mathrm{A})}$ & $21.70 \pm 1.70^{\mathrm{a}(\mathrm{A})}$ & $33.50 \pm 4.30^{\mathrm{b}(\mathrm{A})}$ & $26.80 \pm 1.55^{\mathrm{a}(\mathrm{A})}$ & $8.50 \pm 0.52^{\mathrm{a}(\mathrm{A})}$ \\
\hline \multicolumn{2}{|c|}{$\begin{array}{l}\mathrm{F}_{\text {Density of tracks }}(\mathrm{P}-\mathrm{value}) \\
\mathrm{df}\end{array}$} & $\begin{array}{c}1.50(0.220) \\
3,119 \\
\end{array}$ & $\begin{array}{c}2.71(0.002) \\
3,119\end{array}$ & $\begin{array}{c}1.28(0.284) \\
3,119 \\
\end{array}$ & $\begin{array}{c}20.20(<0.0001) \\
3,119\end{array}$ & $\begin{array}{c}7.11(0.001) \\
3,119 \\
\end{array}$ \\
\hline \multicolumn{2}{|c|}{$\begin{array}{l}\mathrm{F}_{\text {Track forming stage }}(\mathrm{P}-\mathrm{value}) \\
\mathrm{df}\end{array}$} & $\begin{array}{c}0.16(0.001) \\
2,119 \\
\end{array}$ & $\begin{array}{c}5.90(0.004) \\
2,119 \\
\end{array}$ & $\begin{array}{c}8.90(0.002) \\
2,119\end{array}$ & $\begin{array}{c}3.88(0.024) \\
2,119 \\
\end{array}$ & $\begin{array}{c}13.25(<0.0001) \\
2,119 \\
\end{array}$ \\
\hline \multicolumn{2}{|c|}{$\begin{array}{l}\mathrm{F}_{\text {Stage } \times \text { Density }}(\mathrm{P} \text {-value }) \\
\mathrm{df}\end{array}$} & $\begin{array}{c}2.04(0.067) \\
6,119\end{array}$ & $\begin{array}{c}2.14(0.054) \\
6,119\end{array}$ & $\begin{array}{c}1.50(0.186) \\
6,119\end{array}$ & $\begin{array}{c}11.04(0.002) \\
6,119\end{array}$ & $\begin{array}{c}0.48(0.820) \\
6,119\end{array}$ \\
\hline
\end{tabular}

Values are Mean $\pm \mathrm{SE}$.

For each ladybird species, small alphabets represent comparison of means between interfering stages within each density level, and large alphabets in parentheses represent comparison of means between different density levels within each interfering stage.

Similar alphabets indicate lack of significant differences amongst means of a species $\mathrm{P}<0.05$. 


\section{Semiochemicals of conspecific eggs}

Increasing concentrations of surface semiochemicals of conspecific eggs increased their inhibitory effects on oviposition by focal females of all species, with females ovipositing maximally in their absence (Fig. 2).

\section{Tracks of conspecific larvae, adult males and females}

Track forming stages and track densities influenced the oviposition of $\mathrm{Ct}, \mathrm{Pd}$ and Ac females. However, the oviposition of $\mathrm{C} 7$ and $\mathrm{Cs}$ was influenced by the track forming stages and not track densities. Insignificant interactions were observed between track forming stages and their densities in all species except Pd. Oviposition by females of $\mathrm{Ct}, \mathrm{Pd}$ and Ac diminished with increasing track densities of fourth instar larvae, adult males and females (Table 3).

\section{DISCUSSION}

Results reveal that oviposition was influenced by the presence of eggs, fourth instars, pupae (only in Pd), adult males and females, though the degree of inhibition was species-specific. The deterrence was largely densitydependent with species-specific variations. The pattern of egg distribution had a significant effect with clustered eggs inhibiting oviposition more than scattered ones in all ladybirds except Pd. Increasing concentrations of egg surface semiochemicals were also effective in deterring oviposition.

The observed increased oviposition inhibition in the presence of clustered eggs may be attributed to (a) aposematic look of the clusters (Agarwala \& Dixon, 1991, 1993) and/or (b) the species-specific semiochemical odours present on the surface of eggs. Each ladybird species is known to produce species-specific alkanes that constitute semiochemical signatures used for defense (Pasteels et al., 1973; Marples et al., 1989; Dixon, 2000; Hemptinne \& Dixon 2000; Hemptinne et al., 2000b, c; Magro et al., 2007). Adults and neonates are known to use olfactory cues to detect conspecifics (Al Abassi et al., 1998; Schaller \& Nentwig, 2000; Omkar et al., 2004). The results obtained with n-hexane chemical extracts of eggs surface reveal that all species show decreased oviposition responses to these extracts and that the deterrence is density dependent. Thus, it seems that both the actual presence of eggs and their semiochemicals influence oviposition.

The deterrence in oviposition in the vicinity of the fourth instars or their tracks, as observed in the present study, supports findings of earlier researchers, indicating fourth instars to be the most active inhibitors of oviposition (Růžička, 1997, 2001a, b, 2002, 2003, 2006; Yasuda et al., 2000). This was not the case for C. septempunctata, though previous studies have shown that this species actively responds to presence of oviposition deterring allomone (Růžička, 1997, 2001a, b; Doumbia et al., 1998). However, Magro et al. (2007) have also found a relatively weaker response of $C$. septempunctata to its own larval tracks in comparison to that shown by $A$. bipunctata and Adalia decempunctata.
That the larval presence signals danger of egg cannibalism (Banks, 1956; Mills, 1982; Majerus, 1994; Dixon, 2000; Cottrell, 2004) is well established and may cause females to reduce or withhold oviposition at sites with larvae (Agarwala et al., 2003). Restlessness or the tendency to fly away from the area in females may also be a reason for the reduction in egg laying under field conditions (Hemptinne et al., 1992) but not in the laboratory. Presence of pupae did not deter oviposition in ladybird species except for $P$. dissecta, where slight inhibitions are observed with increase in density. This lack of oviposition deterrence is possibly due to the fact that pupae do not seemingly pose any danger to eggs. The results are in agreement with Hemptinne \& Dixon (1991). The pupae used in this study are early ones and whether the late age pupae also have the similar effects will require further experimentation.

Presence of adult males and females had density dependent inhibitory effects on oviposition in all the ladybird species. This may be attributable to one or more of the following: (a) crowding (reported in Sasajiscymnus tsugae (Sasaji \& McClure) and H. axyridis by Flowers et al., 2005 and in P. dissecta by Mishra \& Omkar, 2006) (b) harassment of focal females by males, or (c) disturbance during oviposition. Female expenditure of time and/or energy on avoiding competition or harassment is likely to result in reduced oviposition, as reported in $H$. axyridis and Propylea japonica (Thunberg) by Agarwala et al. (2003) and A. bipunctata by Kajita et al. (2006). A previous study on $P$. dissecta by Mishra \& Omkar (2006) also reports similar results, finding reduction in egg viability in the presence of conspecific males. Soares \& Serpa (2006) have observed no oviposition in Coccinella undecimpunctata $\mathrm{L}$. in the presence of adult $H$. axyridis, but the reverse in case of conspecific adults. Females of C. sexmaculata are known to lay fewer eggs in the presence of an immobilized conspecific adult female (Agarwala et al., 2003), whereas C. septempunctata does not oviposit in the presence of conspecific adult females (Hemptinne et al., 1993). Mishra \& Omkar (2006) have also shown inhibitory effects of female conspecific presence and semiochemicals in $P$. dissecta. The time frame of the above experiments differed, which may also play a role in modifying the extent of the inhibition displayed by the ovipositing females.

Encounters with conspecific adults are known to deter oviposition by gravid females of ladybird species (Seagraves, 2009) and similar interference effects have also been reported in parasitoids (Jackson, 1966; Viktorov, 1968; Holmes, 1972). The deterrence of oviposition by adult males and females in the present study is contradictory to the findings of Doumbia et al. (1998) where no inhibitory effects of adult presence was reported on oviposition by $A$. bipunctata. Our present findings are in agreement to that of Mishra \& Omkar (2006).

The oviposition inhibitory effects of increased density of semiochemicals present either in egg surface or tracks indicate that the effect of these ODPs is density dependent. The effect of the track forming stage was observed 
only in $\mathrm{Ct}, \mathrm{Pd}$ and $\mathrm{Ac}$ and not in $\mathrm{Cs}$ and $\mathrm{C}$. In the three former ladybirds ODPs may be stage specific which is contrary to the previous findings of Mishra \& Omkar (2006) and also to the concept of semiochemical parsimony suggested by Hemptinne \& Dixon, 2000). It is more likely that there may be quantitative differences in the amount secreted by different stages (Seagraves, 2009) with larvae leaving more tracks as they use their anal discs to adhere to surfaces. It has been suggested that larval tracks may be more deterrent than those of adults as larvae are more frequent consumers of ladybird eggs than adults (Cottrell \& Yeargan 1998a, b; Seagraves, 2009). The difference in responses to actual presence versus semiochemical presence could also reflect a difference in the chemistry of tracks versus the larval body surface. Also, the increased deterrence in the case of actual presence vis a vis semiochemical presence probably a combined effect of harassment and chemical tracks, as one can't be present without the other.

The present study establishes that the presence and semiochemicals of different life stages (except pupae) have an inhibitory effect on oviposition by conspecific females in these ladybird species. The degree of inhibition is often species-specific. Of all the experimental species, C. septempunctata was least responsive to both actual conspecific presence and semiochemicals. Our results further provide support to our hypothesis that active stages are likely to be more oviposition deterrent than passive ones. However, the oviposition deterrence appeared to be more density-dependent it is more so in presence interference than in semiochemicals.

ACKNOWLEDGEMENTS. The authors are thankful to the Department of Higher Education for providing financial assistance under the Centre of Excellence program and to the Head, Department of Zoology, University of Lucknow, Lucknow for encouragements.

\section{REFERENCES}

Agarwala B.K. \& Dixon A.F.G. 1991: Cannibalism and interspecific predation in ladybirds. In Polgar L., Chambers R.J., Dixon A.F.G. \& Hodek I. (eds): Behaviour and Impact of Aphidophaga. SPB Academic Publishing, The Hague, pp. 95-102.

Agarwala B.K. \& Dixon A.F.G. 1993: Kin recognition: egg and larval cannibalism in Adalia bipunctata. Eur. J. Entomol. 90: $45-50$.

Agarwala B.K., Yasuda H. \& KajtTA Y. 2003: Effect of conspecific and heterospecific feces on foraging and oviposition of two predatory ladybirds: Role of fecal cues in predator avoidance. J. Chem. Ecol. 29: 357-376.

Al Abassis S., Birkett M.A., Petterson J., Pickett J.A. \& Woodcock C.M. 1998: Ladybird beetle odour identified and found to be responsible for attraction between adults. Cell. Mol. Life Sci. 54: 876-879.

Alhmedi A., Haubruge E. \& Francis F. 2010: Identification of limonene as a potential kairomone of the harlequin ladybird Harmonia axyridis (Coleoptera: Coccinellidae). Eur. J. Entomol. 107: 541-548.

BANKS C.J. 1956: Observations on the behaviour and mortality in Coccinellidae before dispersal from the eggshells. Proc. R. Soc. Lond. (A) 31: 56-61.
Birkett M.A., Campbell C.A.M., Chamberlain K., Guerrieri E., Hick A.J., Martin J.L., Matthes M., Napier J.A., Pettersson J., Pickett J.A., Poppy G.M., Pow E.M., Pye B.J., Smart L.E., Wadhams G.H., Wadhams L.J. \& Woodcock C.M. 2000: New roles for cis-jasmone as an insect semiochemical and in plant defense. Proc. Natl. Acad. Sci. USA 97: 9329-9334.

CHAN F.Y. 1995: Etude des alcaloïdes de Adalia bipunctata (L.) en relation avec le comportement de l'insecte. MSc thesis. Faculté des Sciences Agronomiques, Gembloux, 71 pp.

Cottrell T.E. 2004: Suitability of exotic and native lady beetle eggs (Coleoptera: Coccinellidae) for development of lady beetle larvae. Biol. Control 31: 362-371.

Cottrell T.E. \& Yeargan K.V. 1998a: Influence of a native weed, Acalypha ostryifolia (Euphorbiaceae), on Coleomegilla maculata (Coleoptera: Coccinellidae) population density, predation, and cannibalism in sweet corn. Environ. Entomol. 27: 1375-1385.

Cottrell T.E. \& Yeargan K.V. 1998b: Effect of pollen on Coleomegilla maculata (Coleoptera: Coccinellidae) population density, predation, and cannibalism in sweet corn. Environ. Entomol. 27: 1402-1410.

Dixon A.F.G. 1959: An experimental study of the searching behaviour of the predatory coccinellid beetle Adalia decempunctata (L.). J. Anim. Ecol. 28: 259-281.

Dixon A.F.G. 1997: Patch quality and fitness in predatory ladybirds. In Dettner P. (eds): Vertical Food Web Interactions. Springer, Heidelberg, pp. 205-222.

Dixon A.F.G. 2000: Insect Predator-Prey Dynamics: Ladybird Beetles and Biological Control. Cambridge University Press, Cambridge, $257 \mathrm{pp}$.

Doumbia M., Hemptinne J.L. \& Dixon A.F.G. 1998: Assessment of patch quality by ladybirds: role of larval tracks. Oecologia 113: 197-202.

Evans E.W. \& Dixon A.F.G. 1986: Cues for oviposition by ladybird beetles (Coccinellidae): response to aphids. J. Anim. Ecol. 55: 1027-1034.

Flowers R.W., SAlOM S.M. \& KoK L.T. 2005: Competitive interactions among two specialists predators and a generalist predator of hemlock woolly adelgid, Adelges tsugae (Homoptera: Adelgidae), in the laboratory. Environ. Entomol. 34: $664-675$.

Fréchette B., Dixon A.F.G., Alauzet C. \& Hemptinne J.L. 2004: Age and experience influence patch assessment for oviposition by an insect predator. Ecol. Entomol. 29: 578-583.

Fréchette B., Dixon A.F.G., Alauzet C., Boughenou N. \& Hemptinne J.L. 2006: Should aphidophagous ladybirds be reluctant to lay eggs in the presence of unsuitable prey? Entomol. Exp. Appl. 118: 121-127.

Hatano E., Kunert G., Michaud J.P. \& Weisser W.W. 2008: Chemical cues mediating aphid location by natural enemies. Eur. J. Entomol. 105: 797-806.

Hemptinne J.L. \& Dixon A.F.G. 1991: Why ladybirds have generally been so ineffective in biological control? In Polgar L., Chambers R.J., Dixon A.F.G. \& Hodek I. (eds): Behaviour and Impact of Aphidophaga. SPB Academic Publishing, The Hague, pp. 149-157.

Hemptinne J.L. \& Dixon A.F.G. 2000: Defence, oviposition and sex: semiochemical parsimony in two species of ladybird beetles (Coleoptera: Coccinellidae)? A short review. Eur. J. Entomol. 97: 443-447.

Hemptinne J.L., Dixon A.F.G. \& Coffin J. 1992: Attack strategy of ladybird beetles (Coccinellidae): factors shaping their numerical response. Oecologia 90: 238-245.

Hemptinne J.L., Dixon A.F.G., Doeucet J.L. \& Petersen J.E. 1993: Optimal foraging by hoverflies (Diptera: Syrphidae) 
and ladybirds (Coleoptera: Coccinellidae): mechanisms. Eur. J. Entomol. 90: 451-455.

Hemptinne J.L., Doumbia M. \& Dixon A.F.G. 2000a: Assessment of patch quality by ladybirds: role of aphid and plant phenology. J. Insect Behav. 13: 353-359.

Hemptinne J.L., Dixon A.F.G. \& Gauthier C. 2000b: Nutritive cost of intraguild predation on eggs of Coccinella septempunctata and Adalia bipunctata (Coleoptera: Coccinellidae). Eur. J. Entomol. 97: 559-562.

Hemptinne J.L., Lognay G., Gauthier C. \& Dixon A.F.G. 2000c: Role of surface chemical signals in egg cannibalism and intraguild predation in ladybirds (Coleoptera: Coccinellidae). Chemoecology 10: 123-128.

Hemptinne J.L., Lognay G., Doumbia M. \& Dixon A.F.G. 2001: Chemical nature and persistence of the oviposition deterring pheromone in the tracks of the two spot ladybird, Adalia bipunctata (Coleoptera: Coccinellidae). Chemoecology 11: 43-47.

Hilker M. \& Meiners T. 2002: Chemoecology of Insect Eggs and Egg Deposition. Blackwell, Berlin, 410 pp.

Holmes H.B. 1972: Genetic evidence for fewer progeny and higher percent males when Nasonia vitripennis oviposits in previously parasitized hosts. Entomophaga 17: 79-88.

JACKSON D.J. 1966: Observations on the biology of Craphractus cinctus Walker (Hymenoptera: Mymaridae), a parasitoid of the eggs of Dytiscidae (Coleoptera). Trans. R. Entomol. Soc. Lond. 118: 23-49.

Kajita Y., Yasuda H. \& Evans E.W. 2006: Effects of native ladybirds on oviposition of the exotic species, Adalia bipunctata (Coleoptera: Coccinellidae), in Japan. Appl. Entomol. Zool. 41: 57-61.

KAN E. 1988a: Assessment of aphid colonies by hoverflies. I. Maple aphids and Episyrphus balteatus (De Geer) (Diptera: Syrphidae). J. Ethol. 6: 39-48.

KAN E. 1988b: Assessment of aphid colonies by hoverflies. II. Pea aphids and 3 syrphid species: Betasyrphus serarius (Wiedeman), Metasyrphus frequens Matsumara and Syrphus vitripennis (Meigen). J. Ethol. 6: 135-142.

Kan E. \& Sasakawa M. 1986: Assessment of the maple aphid colony by the hoverfly, Episyrphus balteatus (De Geer) (Diptera: Syrphidae). J. Ethol. 4: 121-127.

Kazana E.T., Pope W., Tibbles L., Bridges M., Pickett J.A., Bones A.M., Powell G. \& Rossiter J.T. 2007 The cabbage aphid: a walking mustard oil bomb. Proc. R. Soc. Lond. (B) 274: 2271-2277.

Kindlmann P. \& Dixon A.F.G. 1993: Optimal foraging in ladybird beetles (Coleoptera: Coccinellidae) and its consequences for their use in biological control. Eur. J. Entomol. 90: 443-450.

KLewer N., RŮŽıčKa Z. \& Schulz S. 2007: (Z)-Pentacos-12-ene, an oviposition deterring pheromone of Cheilomenes sexmaculata. J. Chem. Ecol. 33: 2167-2170.

KosAKI A. \& YAMAOKA R. 1996: Chemical composition of footprints and cuticular lipids of three species of lady beetles. Jpn. J. Appl. Entomol. Zool. 40: 47-53.

Laubertie E., Martini X., Cadena C., Treilhou M., Dixon A.F.G. \& Hemptinne J.L. 2006: The immediate source of the oviposition-deterring pheromone produced by larvae of Adalia bipunctata (L.) (Coleoptera: Coccinellidae). J. Insect Behav. 19: 231-240.

Magro A., Tene J.N., Bastin N., Dixon A.F.G. \& Hemptinne J.L. 2007: Assessment of patch quality by ladybirds: relative response to conspecific and heterospecific larval tracks a consequence of habitat similarity? Chemoecology 17: 37-45.

Magro A., Ducamp C., Ramon-Portugal F., Lecompte E., Crouau-Roy B., Dixon A.F.G. \& Hemptinne J.L. 2010: Ovi- position deterring infochemicals in ladybirds: the role of phylogeny. Evol. Ecol. 24: 251-271.

MaJerus M.E.N. 1994: Ladybirds. Harper Collins, London, 367 pp.

Marples N.M., BRakefield P.M. \& Cowie R.J. 1989: Differences between the 7-spot and 2-spot ladybird beetles (Coccinellidae) in their toxic effects on a bird predator. Ecol. Entomol. 14: 79-84.

Martini X., Haccou P., Olivieri I. \& Hemptinne J.L. 2009: Evolution of cannibalism and female's response to ovipositiondeterring pheromone in aphidophagous predators. J. Anim. Ecol. 78: 964-972.

Meisner M.H., Harmon J.P. \& Anthony R.I. 2011: Response of coccinellid larvae to conspecific and heterospecific larval tracks: a mechanism that reduces cannibalism and intraguild predation. Environ. Entomol. 40: 103-110.

Michaud J.P. \& Jyоті J.L. 2007: Repellency of conspecific and heterospecific larval residues to Hippodamia convergens (Coleoptera: Coccinellidae) ovipositing on sorghum plants. Eur. J. Entomol. 104: 399-405.

Michaud J.P. \& MACKAUER M. 1995: The oviposition behavior of Monoctonus paulensis (Ashmead) (Hymenoptera: Aphidiidae): Factors influencing reproductive allocation to hosts and host patches. Ann. Entomol. Soc. Am. 88: 220-226.

MitLS N.J. 1982: Voracity, cannibalism and coccinellid predation. Ann. Appl. Biol. 10: 144-148.

Mishra G. \& OMKar 2006: Conspecific interference by adults in an aphidophagous ladybird Propylea dissecta (Coleoptera: Coccinellidae): effect on reproduction. Bull. Entomol. Res. 96: 407-412.

Moser S.E., Haynes K.F. \& OBrycki J.J. 2010: Behavioral response to larval tracks and the influence of tracks on intraguild scavenging by coccinellid larvae. J. Insect Behav. 23: $45-58$.

Nakashima Y., Birkett M.A., Pye B.J., Pickett J.A. \& Powell W. 2004: The role of semiochemicals in the avoidance of the seven-spot ladybird, Coccinella septempunctata, by the aphid parasitoid, Aphidius ervi. J. Chem. Ecol. 30: 1103-1116.

Oliver T.H., Timms J.E.L., TAYlor A. \& Leather S.R. 2006: Oviposition responses to patch quality in the larch ladybird Aphidecta obliterata (Coleoptera: Coccinellidae): effects of aphid density, and con- and heterospecific tracks. Bull. Entomol. Res. 96: 25-34.

Omkar, Pervez A. \& Gupta A.K. 2004: Role of surface chemicals in egg cannibalism and intraguild predation by neonates of two co-occurring aphidophagous ladybirds, Propylea dissecta and Coccinella transversalis. J. Appl. Entomol Zool. 128: 691-695.

Pasteels J.M., Daloze D. \& Rowell-Rahier M. 1986: Chemical defense in chrysomelid eggs and neonate larvae. Physiol. Entomol. 11: 29-37.

Pasteels J.M., Deroe C., Trusch B., Breckman J.C., Daloze D. \& Hoоtele C. 1973: Distribution des alcaloides defensifs des Coccinellidae. J. Insect Physiol. 19: 1771-1784.

Pettersson J.A., Quiroz A., Stephansson D. \& Niemeyer H. 1995: Odour communication of Rhopalosiphum padi on grasses. Entomol. Exp. Appl. 76: 325-328.

Pettersson J., Ninkovic V., Glinwood R., Birkett M.A. \& PiCKetT J.A. 2005: Foraging in a complex environment semiochemicals support searching behaviour of the seven spot ladybird. Eur. J. Entomol 102: 365-370.

Pettersson J., Ninkovic V., Glinwood R., Al Abassi S., Birkett M.A., Pickett J.A. \& Wadhams L. 2008: Chemical stimuli supporting foraging behaviour of Coccinella septempunctata L. (Coleoptera: Coccinellidae): volatiles and allelobiosis. Appl. Entomol. Zool. 43: 315-321. 
Quiroz A., Pettersson J., Pickett J.A., Wadhams L. \& NieMEYER H.M. 1997: Key compounds in a spacing pheromone in the bird cherry-oat aphid, Rhopalosiphum padi (L.) (Hemiptera, Aphididae). J. Chem. Ecol. 23: 2599-2607.

RŮŽIČKA Z. 1997: Recognition of oviposition-deterring allomones by aphidophagous predators (Neuroptera: Chrysopidae, Coleoptera: Coccinellidae). Eur. J. Entomol. 94: 431-434.

RŮžIČKA Z. 2001a: Oviposition responses of aphidophagous coccinellids to tracks of ladybird (Coleoptera: Coccinellidae) and lacewing (Neuroptera: Chrysopidae) larvae. Eur. J. Entomol. 98: $183-188$.

RŮžIČKA Z. 2001b: Response of chrysopids (Neuroptera) to larval tracks of aphidophagous coccinellids (Coleoptera). Eur. J. Entomol. 98: 283-285.

RŮŽIČKA Z. 2002: Persistance of deterrent larval tracks in Coccinella septempunctata, Cycloneda limbifer and Semiadalia undecimnotata (Coleoptera: Coccinellidae). Eur. J. Entomol. 99: 471-475.

RŮžIČKA Z. 2003: Perception of oviposition-deterring larval tracks in aphidophagous coccinellids Cycloneda limbifer and Ceratomegilla undecimnotata (Coleoptera: Coccinellidae) Eur. J. Entomol. 100: 345-350.

RŮžıČKA Z. 2006: Oviposition-deterring effects of conspecific and heterospecific larval tracks on Cheilomenes sexmaculata (Coleoptera: Coccinellidae). Eur. J. Entomol. 103: 757-763.

Schaller M. \& Nentwig W. 2000: Olfactory orientation of the seven-spot ladybird beetle, Coccinella septempunctata $(\mathrm{Co}-$ leoptera: Coccinellidae): attraction of adults to plants and conspecific females. Eur. J. Entomol. 97: 155-159.
Seagraves M.P. 2009: Lady beetle oviposition behavior in response to the trophic environment. Biol. Control 51: 313-322.

SOARES A.O. \& SERPA A. 2006: Interference competition between ladybird beetle adults (Coleoptera: Coccinellidae): effects on growth and reproductive capacity. Popul. Ecol. 49: 37-43.

ViKToRov G.A. 1968: The influence of the population density upon the sex ratio in Trissolcus grandis Thoms. (Hymenoptera: Scelionidae). Zool. Zh. 47: 1035-1039.

Wiedemann R., Woodring J., Volkl W. \& Hoffmann K.H. 2004: Amino acid composition of honeydew from aphid species feeding on tansy, Tanacetum vulgare. Mitt. Dt. Ges. Allgem. Angew. Entomol. 14: 459-462.

YASUdA H., TAKAGI T. \& KogI K. 2000: Effects of conspecific and heterospecific larval tracks on the oviposition behaviour of the predatory ladybird, Harmonia axyridis (Coleoptera: Coccinellidae). Eur. J. Entomol. 97: 551-553.

Zhu J., Cosse A.A., Obrycki J.J., Boo K.S. \& Baker T.C. 1999: Olfactory reactions of the twelve-spotted lady beetle, Coleomegilla maculata and the green lacewing, Chrysoperla carnea to semiochemicals released from their prey and host plant: electroantennogram and behavioral responses. J. Chem. Ecol. 25: $1163-1177$.

ZhU J. \& PARK K.C. 2005: Methyl salicylate, a soybean aphidinduced plant volatile attractive to the predator Coccinella septempunctata. J. Chem. Ecol. 31: 1733-1746.

Received December 20, 2011; revised and accepted March 27, 2012 